\title{
The Role of the Destination Image in Creating Memorable Tourism Experience
}

\author{
Didem Kutlu \\ Vocational School of Social Sciences, Akdeniz University, Turkey \\ Hasan Ayyildiz \\ Karadeniz Technical University, Turkey
}

Received: 18 September 2020. Revision received: 6 November 2020. Accepted: 10 November 2021

\begin{abstract}
This study aims to investigate the impact of destination image on memorable tourism experience (MTE). We also analyzed the effect of memorable tourism experience on revisit intention. Since there is a limited number of studies on the relationship between destination image and MTE, this study will contribute to the literature. Non-probability convenience sampling method was used to select the sample. The research was conducted with a total of 707 tourists who visited Antalya, Turkey. The data obtained from the study were analyzed using SPSS 20 and LISREL 8.7 package programs. Hierarchical regression analysis was used to analyze the data in the study. Our results indicate that the dimensions of the destination image, namely natural attractions, cultural attractions, tourism infrastructure, and general infrastructure, significantly influence hedonism and local culture. However, dimensions of destination image partly affect novelty, involvement, meaningfulness, and knowledge. Regarding the second objective, the results revealed that MTE dimensions explained $21.9 \%$ of the variance in revisit intention. Since novelty is an important antecedent of MTE and revisits intention, novelty and initiatives related to the tourism sector should be constantly monitored. Destination management organizations could be contributed to the formation of MTE by increasing the activities such as festivals, competitions, exhibitions and encouraging tourists to participate in these activities. Other managerial implications are discussed based on the study results, and directions for future research are provided.
\end{abstract}

Key Words: Destination image, memorable tourism experience, revisit intention

JEL Classification: Z31, M31

Reference: Kutlu, D., Ayyildiz, H.. (2021). The Role of the Destination Image in Creating Memorable Tourism Experience. Journal of Tourism and Services, 23(12), 199-216. doi: 10.29036/jots.v12i23.303

\section{Introduction}

It is acknowledged worldwide that the destination image perceived by tourists is very important as it affects tourists' decision-making, destination selection, post-trip evaluation, and future behavior (Baloglu \& McClearly, 1999: 869; Buhalis, 2000: 111; Echtner \& Ritchie, 2003: 37; Gallarza et al., 2002: 56). Destination image has critical importance in terms of marketing since it has affected both a person's perception of the destination and their choice of destination (Cooper \& Hall, 2008: 223).

The image has become more important than tangible resources due to the characteristics of tourism, such as the intangible structure and the inseparability of production and consumption. Hence, perceptions rather than reality drive consumers to act or not act (Gallarza et al., 2002: 57). There is a general concurrence that the destination image has an impact on the tourist's decision making and selection process (Alhemoud \& Armstrong, 1996: 76; Baloglu \& McClearly, 1999: 868; Beerli \& Martin, 2004: 623; Bigne et al., 2001: 607; Chen \& Tsai, 2007: 1115; Fakeye \& Crompton, 1991: 10; Hui \& Wan, 
2003: 306; Souiden et al., 2017: 55; Tasci \& Gartner, 2007: 413). The role of image is exclusively important in the destination choice process, when there is limited personal experience (Crompton, 1979: 18). It is considered that destinations with a strong positive image will be selected with a higher probability in the decision-making process (Alhemoud \& Armstrong, 1996: 77; Echtner \& Ritchie, 2003: 37). Creating an image for a touristic destination provides an effective strategy and competitive advantage in the market (Buhalis, 2000: 113; Gallarza et al. 2002: 71).

The common point of the studies related to destination image is its significant contribution to the decision-making process, purchase and revisit intention of consumer. In today's world of fierce competition, it is not adequate to differentiate merely physical elements in attracting foreign investments, trade and tourists to the destination. Therefore, many businesses attempt to create a unique consumer experience in order to differentiate their goods or services. After the concept of experience has been subjected to consumption and marketing by Holbrook and Hirschman (1982), businesses have started to give importance to producing experience-oriented goods and services rather than pure consumption. Experience has been playing a key role in tourism research in recent years. Everything that a tourist goes through in a destination can be an experience as cognitive or emotional, behavioural or perceptual, explicit or implied (Oh et al. 2007: 120). In order remember a consumer experience as a tourism experiences, it has to be remembered after a touristic event happened (Kim et al., 2012: 13). Since MTE is an emerging research subject, academic research on MTE remains sparse. Therefore, more research could provide a better understanding of MTE formation process and its antecedents.

This study aims to assess how foreign tourists' destination image influence memorable tourism experience in Antalya which is a popular destination in Turkey with a long tradition in tourism. In addition, the study intends to investigate the effects of MTE on revisit intention. This study also contributes to the field by providing practical information of how to increase MTE and revisit intention. In the following section we briefly review existing literature concerning destination image and MTE.

\section{Theoretical Background and Hypothesis}

\subsection{Destination Image}

Destination image is one of the important factors that increase competitiveness in the international tourism market in Turkey. Destination image, which has been studied by researchers for the last 30 years, is the individual's perception of a place. Individuals form this image with the information they obtain from various sources.

The most accepted definition of destination image is Crompton's (1979: 18) "the sum of beliefs, ideas and impressions that a person has of a destination". According to Gunn (1997: 120), the destination image consists of two components, the induced image and the organic image. Induced image is an important element that triggers visits to the destination such as advertisement and promotion. On the other hand, organic image occurs through non-commercial sources of information during media, popular culture and education, and is often uncontrollable. According to Kotler et al. (1993: 35), destination image is a set of a person's ideas, beliefs, feelings, expectations and impressions of a place or destination. As stated by Baloglu and McClearly (1999: 870), destination image is an attitudinal structure consisting of the knowledge, belief, and global impression of the individual in relation to an object or destination. As stated by Baloglu and McClearly (1999: 870), destination image is an attitudinal construct that consists of a person's belief, knowledge, and total impression about an object or destination.

Destination image theories are divided into two areas. The first indicates that the destination image can be separated into many attributes and elements that can be measured. The second is the gestalt approach which effectively states that the image is in a whole or holistic concept and cannot be separated (Cooper \& Hall, 2008: 224). According to Gartner in the first approach, the destination image consists of cognitive, affective and conative components. The cognitive component refers to the beliefs and 


\section{JOURNAL OF TOURISM AND SERVICES}

Issue 23, volume 12, ISSN 1804-5650 (Online)

www.jots.cz

attitudes towards the destination and leads to an internal evaluation of destination attributes (Gartner, 1993). The affective component of image is related to the value of the tourist's expectation from the destination based on his/her emotions or motives. This value emerges as a result of comparing the needs of the tourist with this image. The conative component is the action component which based on behavioural intention (Cooper and Hall, 2008: 225).

It has been supported by previous research that the destination image has a significant impact on the decision-making and selection process (Alhemoud \& Armstrong, 1996: 76; Baloglu \& McClearly, 1999: 868; Beerli \& Martin, 2004: 623; Bigne et al. 2001: 607; Chen \& Tsai, 2007: 1115; Fakeye \& Crompton, 1991: 10; Hui \& Wan, 2003: 306; Souiden et al. 2017: 55; Tasci \& Gartner, 2007: 413). When there is a limited personal experience, the image is especially important to determine a destination (Crompton, 1979: 18). Image exists in all of the consumer experience. It provides indirect consumption through browsing and shopping at the pre-consumption stage. During the consumption phase, the image adds value to the product and increases consumer's satisfaction. After consumption, image has a constructive role in which experience is re-lived through memories and souvenirs (MacInnis \& Price, 1987: 483). Image is very important to increase remembered satisfaction and encourage repurchase actions.

In terms of evaluating and measuring the destination image, there are two approaches: structured and unstructured. The structured methodologies are easy to apply and analyze, and the Semantic differential scale or Likert type scales are used to measure image attributes. (Gallarza et al. 2002: 60). The unstructured methodologies are appropriate for both measuring the holistic components of the image and capturing unique attributes. Various techniques such as content analysis, focus group interviews, open-ended questions are used to determine the image dimensions (Echtner \& Ritchie, 2003: 44). The cognitive component of destination image included 4 dimensions and 12 items derived from the studies of Baloglu \& McClearly,1999; Beerli \& Martin, 2004; Martinez \& Alvarez, 2010 were used in this study. The destination image consists of four constructs identified as natural attractions, cultural attractions, tourism infrastructure and general infrastructure. Each construct was measured using four items. Since they have been used commonly to measure cognitive component in previous studies (Jenkins, 1999: 11), these constructs were selected in our study.

In recent years, according to the arrival of international tourists, Turkey has found its place in the world's top 10 destinations in a manner consistent. According to the World Tourism Organization, with the number of tourists 51.2 million, Turkey is ranked 6th in 2019. Antalya contributes to the formation of this ranking by taking the first place with $62.19 \%$ (Ministry of Culture and Tourism). Antalya is a popular destination and attracts tourists with its historical, natural and cultural beauties. Therefore, it has been the focus of many destination image studies in the academic field.

Over the years, numerous studies have been carried out to understand the role of destination image on tourist's behavioural intentions (Baloglu \& McClearly, 1999; Bigne et al. 2001; Beerli \& Martin, 2004: 623; Chen \& Tsai, 2007: 1115; Fakeye \& Crompton, 1991; Souiden et al. 2017: 55; Tasci \& Gartner, 2007: 413). However, a few studies explored the relationship between destination image and MTE. For example, Tukamushaba et al. (2016) found that tourists' perceptions of the tourism product have a positive effect on MTE. In their study, they examined the tourism product in four dimensions: attractions, ancillary services, amenities and accommodation. Ersoy found a relationship between perception of destination image and memorable tourism experiences (MTE) of Russian tourists visited Turkey (Ersoy, 2015: 82). Kim determined that the destination characteristics, namely local culture, diversity of activities, hospitality, infrastructure, environmental management, accessibility, quality of service, geography, spatial commitment and superstructure affect MTE (Kim, 2014: 43). Since it is considered that destination image has an impact on MTE, the following hypothesis is proposed:

$\mathrm{H}_{1}$ : Destination image has a positive effect on MTE 


\section{JOURNAL OF TOURISM AND SERVICES}

Issue 23, volume 12, ISSN 1804-5650 (Online)

www.jots.cz

\subsection{Memorable Tourism Experience}

Tourism is an experience-intensive industry in which consumers are willing to pay experiences they enjoy (Barnes et al. 2016: 287). Tourism is about the experience of visiting, seeing, learning, enjoying and living differently from the regular life of tourists. Therefore, behavioural or perceptual, cognitive or emotional, explicit or implied thing that a tourist meets in a destination can be an experience (Oh et al. 2007: 120). "MTEs are those experiences that are selectively constructed from tourist experiences and can be recollected after a trip", defined by Kim et al. (2012). Nowadays, it is very important to gain memorable experiences for sophisticated and demanding consumers. In addition, the key to gain sustainable competitive advantage for businesses is to provide tourists with unique, exceptional and memorable experiences (Chandralal and Valenzuela, 2013: 177).

The importance of MTE stems from the effect of past memories on consumer decision making. Numerous researchers have emphasized that past memories are the most important source of information that a tourist intends to revisit a specific destination (Chandralal \& Valenzuela, 2013: 177; Chen \& Rahman, 2018: 159; Kim \& Ritchie, 2014: 331). According to Hoch and Deighton, consumers pay more attention to their conclusions from past experiences. One of the reasons is that if the information is obtained from past experiences, motivation and involvement tend to be higher. Secondly, consumers tend to perceive past experiences as reliable and credible information sources. Finally, past experiences have a great influence on behaviour (Hoch and Deichton, 1989: 2).

Kim et al. (2012: 20) have developed factors to characterize MTE. According to the scale they developed, MTE consists of seven dimensions: hedonism, refreshment, local culture, meaningfulness, knowledge, involvement and novelty. Hedonic consumption reveals that consumers seek fun, amusement, arousal, fantasy, sensory stimulation, and enjoyment (Holbrook \& Hirschman, 1982: 135). Hedonism is an integral part of leisure experiences and is an important factor in determining future behaviour as well as the satisfaction of tourists (Duman and Mattila, 2005: 313). Refreshment refers to the sense of relaxation and renewal (Zhong et al., 2017: 204). Refreshment is the most decisive basic component of tourism activities. The experience of feeling refreshment increases the recall of the past experiences vividly (Kim, 2010: 791). Kim and Ritchie (2014) defined local culture as the social interaction with local people, their life, and their environment. Chandralal and Valenzuela have shown that staying close to local life, attending local cultural ceremonies and tasting local food helps create positive memories in the minds of travellers (Chandralal \& Valenzuela, 2013: 178). Local people's lifestyle and knowledge about local culture has significantly increased MTE (Tung \& Ritchie, 2011: 1379). As stated by Zhong et al. (2017), meaningfulness is the physical consummation and affectional/spiritual meanings derived from a tourism experience. A meaningful tourist experience is positive and memorable and leads to tourist's personal development and change. After returning home, daily life can be seen in a completely new way (Tarssanen, 2009: 6). Knowledge refers to learn new things and gain insights after tourism experience. One of the factors that encourage individuals to travel is to meet the need for information. For instance, many individuals travel in response to the urge to gain and understand new information about the places they visit (especially in terms of geography, history, language and culture) (Kim and Ritchie, 2014: 325). According to Pine and Gillmore, participation or involvement, one of the four areas of experience, occurs in two ways, active and passive. In passive participation, the individual experiences the event as an observer or listener. In active participation, the person plays an active role in the performance or activity that will provide experience (Pine \& Gillmore, 1998: 101). Novelty is one of the main motivations that enable travellers to search for new and different experiences (Duman \& Mattila, 2005: 313). Novelty includes travel experiences related to doing something unusual (Chandralal \& Valenzuela, 2013: 179).

Since MTE has affected destination choices, it is very important for businesses that want to ensure destination competition and sustainability. If memorable experiences are provided to tourists at the destination, tourists will be more likely to visit this destination again (Zhang et al., 2018: 329). Aslan found that creative experiences have a positive effect on destination loyalty (Aslan, 2018: 112). Ali et al. (2014) suggest four dimensions of customer experience including entertainment, education, aesthetic and 


\section{JOURNAL OF TOURISM AND SERVICES}

Issue 23, volume 12, ISSN 1804-5650 (Online)

www.jots.cz

escapism can develop memories of consumers which can ultimately influence their loyalty behaviours. Unal and Bayar (2020) found a positive strong relationship between MTE and revisit intention of local tourists visited Antalya. Similar studies support that MTE has a positive effect on the customer's behaviour intention and loyalty (Chen \& Rahman, 2018: 153; Duman \& Mattila, 2005:311; Mahdzar et al., 2015: 32). Since MTE is considered to have a positive effect on revisit intention, the following hypothesis is proposed:

$\mathrm{H}_{2}$ : MTE has a positive effect on revisit intention

\section{Methodology}

The aim of the study is to explore the relationship between destination image, MTE and revisit intention. Based on the effects of destination image on satisfaction and behavioural intention (Baloglu \& McClearly, 1999; Bigne et al. 2001; Beerli \& Martin, 2004: 623; Chen \& Tsai, 2007: 1115), this study will investigate the role of destination image in MTE formation. If tourists are more affected by the destination (e.g., friendly people, beautiful natural landscapes), they are likely to acquire MTEs, which will lead to more revisit intentions (Zhang et al., 2018: 327). Therefore, the following hypotheses were formulated to test the relationship between destination image, MTE and revisit intention:

$\mathrm{H}_{1}$ : Destination image has a positive effect on MTE

$\mathrm{H}_{1 \mathrm{a}}$ : Destination image has a positive effect on hedonism

$\mathrm{H}_{1 \mathrm{~b}}$ : Destination image has a positive effect on novelty.

$\mathrm{H}_{1 \mathrm{c}}$ : Destination image has a positive effect on local culture.

$\mathrm{H}_{1 \mathrm{~d}}$ : Destination image has a positive effect on meaningfulness.

$\mathrm{H}_{1}$ : Destination image has a positive effect on involvement.

$\mathrm{H}_{1 \mathrm{f}}$ : Destination image has a positive effect on knowledge.

The destination image consists of 4 dimensions: natural attractions, cultural attractions, tourism infrastructure and general infrastructure. Therefore, in the study, hypotheses as above were established for each dimension separately.

$\mathrm{H}_{2}$ : MTE has a positive effect on revisit intention

$\mathrm{H}_{2 \mathrm{a}}$ : Hedonism has a positive effect on revisit intention.

$\mathrm{H}_{2 \mathrm{~b}}$ : Novelty has a positive effect on revisit intention.

$\mathrm{H}_{2 \mathrm{c}}$ : Local culture has a positive effect on revisit intention.

$\mathrm{H}_{2 \mathrm{~d}}$ : Meaningfulness has a positive effect on revisit intention.

$\mathrm{H}_{2 \mathrm{e}}$ : Involvement has a positive effect on revisit intention.

$\mathrm{H}_{2 \mathrm{f}}$ : Knowledge has a positive effect on revisit intention.

Factor analysis was performed for the construct validity of the scales and then Cronbach's Alpha coefficients were calculated for reliability analysis. Confirmatory factor analysis was also performed with the LISREL package program for the analysis of the data. As a result of the preliminary study, it was considered appropriate to use hierarchical regression analysis to test hypothesis. This technique allows evaluating the changes in the explained variance ratio $\left(\mathrm{R}^{2}\right)$ by including additional variables gradually (De Vita et al., 2010: 662). 


\section{JOURNAL OF TOURISM AND SERVICES}

Issue 23, volume 12, ISSN 1804-5650 (Online)

www.jots.cz

\subsection{Data Collection}

Antalya province, located south of Turkey on the Mediterranean coast, is one of Turkey's most important tourism destinations (Figure 1). Antalya, which has 630 kilometres of coastal area, is a destination known as 3S (sea, sand, sun), and attracts tourists with its natural, cultural and historical beauties. Antalya ranked 10th with 12.41 million international visitors, according to the Global Destination Cities Index 2019, organized by Mastercard, which analyzes top travel destinations, visitor volume and expenditure (Global Destination Cities Index 2019: 3). In terms of cultural attractions of Antalya, Saint Nicholas Church, Myra Ancient City, Termessos Ancient City, Historical Clock, Olympos Ancient City, Apollon Temple, Perge Ancient City, Aspendos Theater can be given as examples. According to the data of the Ministry of Culture and Tourism in 2019, 3.087 .871 people visited Antalya museums and archaeological sites. In addition, Antalya hosts events such as festivals, concerts and theatres. Natural attractions consist of climate, beaches, waterfalls, caves, mountains, national parks. Mediterranean climate and long coastline beaches (Patara, Kleopatra, Lara, Konyaalt1, Kemer, Incekum, Kaputass, Kundu, Phaselis etc.) are the basic elements that are effective in the development of tourism.

Tourism infrastructure include all institutions and organizations that meet the needs of tourists such as accommodation and catering establishments, shopping centers and healthcare units (Türkay ve Saraç, 2019: 99). According to the data of the Ministry of Culture and Tourism, there are total of 1.926 accommodation establishments in Antalya of which bed capacity is 643.566 (Ministry of Culture and Tourism, 2020). The all-inclusive system, which is an important element in the marketing of hotels by tour operators, is used in 450 of the accommodation businesses in Antalya (Ipsos report, 2020). The allinclusive system consists of accommodation, meals, snacks, local alcoholic and non-alcoholic hot and cold drinks, entertainment, limited land sports and children's clubs (Üner et al., 2006: 36). The general infrastructure of a destination consists of water, sewage systems, energy resources, health services, garbage and drainage systems, communication network, destination streets and streets, subway, tunnel and security systems (Türkay \& Saraç, 2019: 99).

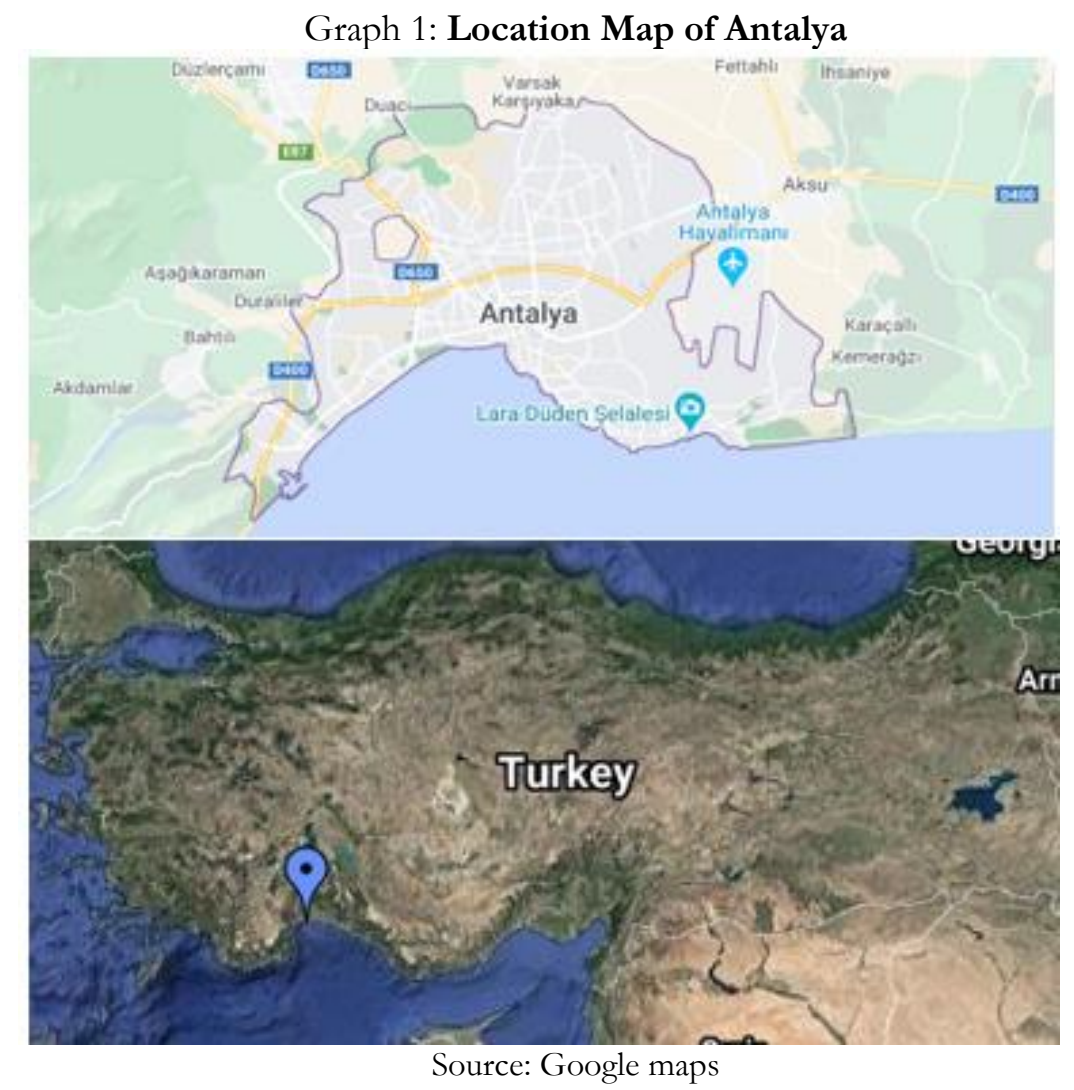




\section{JOURNAL OF TOURISM AND SERVICES}

Issue 23, volume 12, ISSN 1804-5650 (Online)

www.jots.cz

International tourists visited Antalya were defined as the target study population. The survey was conducted in Antalya, one of the most visited cities in Turkey. Convenience sampling method was used as the sampling procedure. A convenience sample is defined as a non-probability method where subjects are selected because of their convenient accessibility (Gegez, 2014: 217). The data were collected from May to October 2018. On a voluntary basis, a questionnaire was applied to international tourists in tour buses, tourist centres such as hotels and restaurants through tour guides. A total of 812 questionnaires were distributed and after deletion of incomplete responses, 707 questionnaires were used for statistical analyses.

\subsection{Measurement}

Destination image items were adapted from previous studies (Baloğlu \& McClearly,1999: 881; Beerli \& Martin, 2004: 625; Martinez \& Alvarez, 2010: 754). It includes four dimensions and 12 items: namely natural attractions, cultural attractions, tourism infrastructure and general infrastructure. Memorable Tourism Experience was operationalized using six constructs (hedonism, refreshment, local culture, meaningfulness, knowledge, involvement and novelty) adapted from Kim et al. (2012: 18). Revisit intention is measured by four items, including revisit propensity, revisit willingness, revisit probability in near future and recommendation to family and friends (Nadeau et al., 2008: 95). All the items were measured using a five-point Likert scale, ranging from 1 (strongly agree) to 5 (strongly disagree). The questionnaire was written in Turkish firstly and then translated to German, English and Russian by bilingual experts. A pilot study was conducted with 52 respondents in order to test the clarity and comprehensibility of the questions. According to the results of the pilot study, changes were made as required.

\subsection{Data Analysis}

Data analysis was conducted using the SPSS 20.0 and LISREL 8.7. Descriptive statistical analysis, reliability and validity analysis, factor analysis, hierarchical regression analysis were performed. The study used LISREL 8.7 for data analysis with confirmatory factor analysis (CFA) as the initial stage. Hierarchical regression analysis was conducted to test hypotheses.

\subsection{Profile of Respondents}

The demographics of the 707 respondents were aged 21 and 40 years (51.06\%) and consists mostly female $(55.03 \%)$. Most of respondents (45.55\%) had secondary and high school education degree, $38.75 \%$ of respondents had undergraduate education degree. Most of respondents $(55.02 \%)$ were married. Of those surveyed $40.45 \%$ had visited the city of Antalya two to three times while $30.27 \%$ were first time visitors. Most of the respondents were Dutch (30.27\%), Russian (21.22\%) and German $(16.83 \%)$ tourists, respectively. According to the data of the Ministry of Culture and Tourism, the nationalities of the tourists, visited our country in 2018 consists of Russian, German and British, respectively. In our study, the reason of why the Dutch tourists are among top three is thought that the surveys were applied to tour groups concentrated in certain regions during the summer season.

\subsection{Reliability and Validity}

Cronbach's alpha was used to assess the reliability of each construct in our study. All the reported reliability coefficients exceed .70 (Table 1) which suggested acceptable internal consistency (Nunnally, 1978). The Cronbach's Alpha of destination image construct is between .773 and .862 which shows high reliability. 


\section{JOURNAL OF TOURISM AND SERVICES}

Issue 23, volume 12, ISSN 1804-5650 (Online)

www.jots.cz

This study employs factor analysis to test the construct validity. Factor loadings should be greater than .5 (Nunnally, 1978). All factor loadings of these measurements were greater than .679 except three general infrastructure items. These items, "the development and quality of airport and port is good; Turkey's private and public transport facilities are adequate", were deleted because of low loadings and therefore were not included in further analysis. The exploratory factor analysis procedure led to retaining of 12 items. The first factor explains $20.655 \%$ of the total variance. Four factors explain $73.539 \%$ of the total variance.

Table 1: Factor Loadings and Cronbach Alpha Values of Destination Image Construct

\begin{tabular}{|l|l|l|l|}
\hline Items & \% of variance extracted & Reliability & $\begin{array}{l}\text { Factor } \\
\text { Loadings }\end{array}$ \\
\hline General Infrastructure & 20.655 & .862 & \\
$\begin{array}{l}\text { Development of health services } \\
\text { Development of telecommunication service } \\
\text { Development of commercial infrastructure }\end{array}$ & & & .839 \\
\hline $\begin{array}{l}\text { Tourism Infrastructure } \\
\text { A good shopping environment }\end{array}$ & 17.841 & .827 \\
Suitable accommodation & & .785 & .808 \\
A rich cuisine & & & .784 \\
\hline $\begin{array}{l}\text { Cultural Attractions } \\
\text { Historical and cultural heritages }\end{array}$ & 17.766 & .771 \\
Unique historical culture & & .805 & .728 \\
Unique lifestyle and custom & & & .814 \\
\hline $\begin{array}{l}\text { Natural Attractions } \\
\text { Clean } \\
\text { The environment is not polluted } \\
\text { A good natural environment }\end{array}$ & 17.278 & .787 \\
\hline
\end{tabular}

A confirmatory factor analysis was used to test the measurement structure of destination image. A total of 12 items were included in the measurement of destination image. Several indices describe overall model fit of a model in LISREL to assess the fitting level between observed data and a model, including chi-square $\left(\chi^{2}\right)$, goodness-of-fit index (GFI), adjusted goodness-of-fit index (AGFI), root mean square residual (RMR), $\chi 2$ ratio, and incremental fit index (IFI). The recommended cut-off value for GFI, NFI, or CFI is $\geq .90$ (Hu and Bentler 1998). It has been suggested that RMSEA values less than .05 are good, values between .05 and .08 are acceptable, values between .08 and .1 are marginal, and values greater than 0.1 are poor (MacCallum et al., 1999). The measurement model in this study resulted in good fit $\left(\chi^{2} / \mathrm{df}=3.82\right.$, CFI $=.97$, RMSEA $\left.=.063\right)$, based on the selected approximation fit indices. Since the measurement model fit values were within the desired range, the 4-factor structure of the destination image scale was confirmed.

Cronbach's alpha for MTE construct was calculated to assess reliability. As shown in Table 2, when the alpha coefficients from the current data are evaluated, it is seen that the structures can be used with confidence. The results show high reliability. The factor solution for each group produced factor loadings that met and exceeded the threshold value of $>.40$ (Hair et al. 1998), except refreshment factor. Therefore, refreshment factor (i.e. "it was liberating", "I enjoyed a sense of freedom", "it was refreshing", "I was revitalized through this tourism experience" were eliminated and were not included in further analysis. The final result of the EFA indicated that there were six MTE factors, explaining $71.52 \%$ of the variance. 
Table 2: Factor Loadings and Cronbach Alpha Values of MTE Construct

\begin{tabular}{|l|l|l|l|}
\hline Items & $\begin{array}{l}\text { \% of variance } \\
\text { extracted }\end{array}$ & Reliability & $\begin{array}{l}\text { Factor } \\
\text { Loadings }\end{array}$ \\
\hline Hedonism & 14.912 & .856 & .804 \\
Indulged in the activities during this trip & & .801 \\
Really enjoyed the trip & & .761 \\
Thrilled about this tourism experience & & .603 \\
Exciting & & & \\
\hline Novelty & 13.427 & .820 & .787 \\
I've experienced this destination once in a lifetime. & & .714 \\
This experience was different from my previous trips & & .644 \\
Experienced something new during this trip & & .624 \\
This destination offered me a unique experience & 12.101 & \\
\hline Knowledge & & .765 \\
I gained knowledge or information during this trip & & .746 \\
I learned new skills/games/activities during this trip & & .699 \\
It was exploratory & & & \\
\hline Meaningfulness & & & .781 \\
I did something meaningful during my trip & & .726 \\
I did something important during my trip & & .716 \\
\hline Learned about myself & & & \\
\hline Involvement & & & .823 \\
I visited a place I would love to visit. & & & .800 \\
I really enjoyed tourism activities that I wanted to do & & .662 \\
I joined in tourism activities that I have been concerned & & .626 \\
\hline Local Culture & & .7929 \\
Local people in Antalya were friendly to me & & .782 \\
I experienced the local culture of Antalya closely. & & .499 \\
\hline
\end{tabular}

Source: own processing

According to CFA, results showed overall good fit indices for MTE $(\chi 2 / \mathrm{df}=3.15$, CFI $=0.95$, RMSEA $=0.05)$, proving that the indicators are acceptable and support good model fit.

It is suggested that the reliability coefficient will be sufficient since revisit intention scale is not suitable for factor analysis as a one-dimensional structure. Accordingly, the Cronbach alpha value of revisit intention scale was .868 . Since Cronbach alpha value is above .70 , it can be suggested the scale is reliable. The above analyses strongly supported the validity of all the measured constructs.

\section{Results}

Hierarchical regression analysis is used to test models established for multiple independent variables to explain one dependent variable. This regression method has been widely used in previous research where both major effects and interaction effects are investigated (Lyu et al. 2020: 55). Hierarchical regression is used to determine whether a statistically significant amount of variance is explained in the dependent variable after adding the independent variables (Kim, 2016).

Table 3: Results of Hierarchical Regression Analysis of the Effects of Destination Image Dimensions on Hedonism

\begin{tabular}{|l|llllllll|}
\hline Independent variables & Model 1 & \multicolumn{3}{l}{ Model 2 } & \multicolumn{3}{c}{ Model 3 } & \multicolumn{2}{c|}{ Model 4 } \\
\cline { 2 - 8 } & $\mathrm{B}$ & $\mathrm{p}$ & $\mathrm{B}$ & $\mathrm{p}$ & $\beta$ & $\mathrm{p}$ & $\beta$ & $\mathrm{p}$ \\
\hline NA & .306 & .000 & .199 & .000 & .183 & .000 & .149 & $.000^{*}$
\end{tabular}




\begin{tabular}{|c|c|c|c|c|c|c|c|}
\hline CA & & .264 & .000 & .186 & .000 & .168 & $.000^{*}$ \\
\hline TI & & & & . 128 & .006 & . 104 & $.028 *$ \\
\hline GI & & & & & & . 102 & $.018^{*}$ \\
\hline Mod & & & & & & & \\
\hline F & 72.716 & 63.078 & & 44.987 & & 35.373 & \\
\hline $\mathrm{R}^{2}$ & .093 & .152 & & .161 & & .168 & \\
\hline$\Delta \mathrm{R}^{2}$ & .092 & .150 & & .157 & & .163 & \\
\hline
\end{tabular}

Note: $\mathrm{NA}=$ natural attractions, $\mathrm{CA}=$ cultural attractions, $\mathrm{TI}=$ tourism infrastructure, $\mathrm{GI}=$ general infrastructure * Significance at $\mathrm{p}<.05$

Source: own processing

Table 3 shows the results of hierarchical regression analysis of the effects of destination image dimensions on hedonism. According to Model 1, natural attractions (NA) significantly affects the hedonism of MTE $\left(\mathrm{R}^{2}=.093 ; \mathrm{p}<.05\right)$. Next adding cultural attractions $(\mathrm{CA})$ in Model 2 leads to a significant change in $\mathrm{R}^{2}\left(\mathrm{R}^{2}=.152, \mathrm{p}<.05\right)$. The $\mathrm{CA}$ shows a significant positive relationship with hedonism $(\beta=.264)$. When tourism infrastructure (TI) was regressed on hedonism (model 3 ), the coefficient of TI was significant and positive $(\beta=.128)$. The explanatory power was reached $16.1 \%$ $\left(\mathrm{R}^{2}=.161, \mathrm{p}<.05\right)$ in Model 3 which explains $16.1 \%$ variance in hedonism. In Model 4, general infrastructure (GI) was added. Together, NA, CA, TI and GI explained $16.3 \%$ of the variance in hedonism. Models 1 through 4 in Table 3 consistently show that destination image positively affects hedonism. Therefore, $\mathrm{H}_{1 \mathrm{a}}$ is supported.

Table 4: Results of Hierarchical Regression Analysis of the Effects of Destination Image Dimensions on Novelty

\begin{tabular}{|l|cccc|cccc|}
\hline \multirow{2}{*}{ Independent variables } & \multicolumn{2}{|c}{ Model 1 } & \multicolumn{2}{c}{ Model 2 } & \multicolumn{3}{c|}{ Model 3 } & \multicolumn{2}{c|}{ Model 4 } \\
\cline { 2 - 9 } & $\beta$ & $\mathrm{p}$ & $\mathrm{B}$ & $\mathrm{p}$ & $\beta$ & $\mathrm{p}$ & $\beta$ & $\mathrm{p}$ \\
\hline NA & .319 & .000 & .215 & .000 & .210 & .000 & .154 & $.000^{*}$ \\
CA & & & .256 & .000 & .231 & .000 & .200 & $.000^{*}$ \\
TI & & & & & .042 & .370 & .002 & .958 \\
GI & & & & & & & .169 & $.000^{*}$ \\
Model summary & & & & & & & & \\
F & 79.723 & & 65.311 & & 43.797 & & 37.438 & \\
$\mathrm{R}^{2}$ & .102 & & .157 & & .157 & & .176 & \\
$\Delta \mathrm{R}^{2}$ & .100 & & .154 & & .154 & & .171 & \\
\hline
\end{tabular}

Note: $\mathrm{NA}=$ natural attractions, $\mathrm{CA}=$ cultural attractions, $\mathrm{TI}=$ tourism infrastructure, $\mathrm{GI}=$ general infrastructure $*$ Significance at $\mathrm{p}<.05$

\section{Source: own processing}

Model 1 in Table 4 shows that NA were able to explain $10.2 \%$ of the variance in novelty $\left(\mathrm{R}^{2}=\right.$ $.102, \mathrm{p}<.05)$ significant. The coefficient of NA was statistically positive $(\beta=.319)$. In Model 2, CA were added. The explanatory power was reached at $15.7 \%\left(\mathrm{R}^{2}=.157, \mathrm{p}<.05\right)$. The $\beta$ value of $\mathrm{CA}$ was greater than zero, indicating that its impact on novelty was positive. In Model 3 the $\beta$ value of TI was greater than zero, indicating positive impact on novelty. However, the independent variable of TI was not significant $(\beta=.062, \mathrm{p}>.05)$. Adding GI in Model 4 leads to a significant change in $\mathrm{R}^{2}\left(\mathrm{R}^{2}=.176, \mathrm{p}<.05\right)$ which explains $17.6 \%$ variance in novelty together with NA, CA and TI. Since the dimension of tourism infrastructure was insignificant, $\mathrm{H}_{1 \mathrm{~b}}$ is partially supported. 
Table 5: Results of Hierarchical Regression Analysis of the Effects of Destination Image Dimensions on Local Culture

\begin{tabular}{|l|llllllll|}
\hline \multirow{2}{*}{ Independent variables } & Model 1 & \multicolumn{3}{l}{ Model 2 } & \multicolumn{3}{c|}{ Model 3 } & \multicolumn{3}{c|}{ Model 4 } \\
\cline { 2 - 9 } & $\beta$ & $\mathrm{p}$ & $\mathrm{B}$ & $\mathrm{p}$ & $\beta$ & $\mathrm{p}$ & $\beta$ & $\mathrm{p}$ \\
\hline NA & .330 & .000 & .196 & .000 & .173 & .000 & .137 & $.000^{*}$ \\
CA & & & .333 & .000 & .221 & .000 & .201 & $.000^{*}$ \\
TI & & & & & .185 & .000 & .160 & $.000^{*}$ \\
GI & & & & & & & .109 & $.009^{*}$ \\
Model summary & & & & & & & & \\
F & 86.404 & & 89.177 & & 66.490 & & 52.007 & \\
$\mathrm{R}^{2}$ & .109 & & .202 & & .221 & & .229 \\
$\Delta \mathrm{R}^{2}$ & .108 & & .200 & & .218 & & .224 & \\
\hline
\end{tabular}

Note: $\mathrm{NA}=$ natural attractions, $\mathrm{CA}=$ cultural attractions, $\mathrm{TI}=$ tourism infrastructure, $\mathrm{GI}=$ general infrastructure

* Significance at $\mathrm{p}<.05$

Source: own processing

Table 5 shows the results of hierarchical regression analysis of the effects of destination image dimensions on local culture. It was observed that NA explained $10.9 \%$ of local culture and the influence of NA was significant $\left(\mathrm{R}^{2}=.109, \mathrm{p}<.05\right)$. When CA was included in Model 2 , the explanatory power was reached at $20.2 \%\left(\mathrm{R}^{2}=.202, \mathrm{p}<.05\right)$. The largest contribution was $\mathrm{CA}(\beta=.333)$. In Model 3 , TI was added, which explained an additional $22.1 \%$ of the variance in local culture $\left(\mathrm{R}^{2}=.221, \mathrm{p}<.05\right)$. The $\beta$ value of TI was .185, indicating that its impact on local culture was positive. In Model 4 GI was added. The explanatory power was reached at $22.9 \%$, indicating that together NA, CA, TI and GI explained $22.9 \%$ of local culture $\left(\mathrm{R}^{2}=.229, \mathrm{p}<.05\right)$. The coefficient of GI was positive $(\beta=.109)$ which explained positive impact on local culture. Therefore, $\mathrm{H}_{1 \mathrm{c}}$ is supported.

Table 6: Results of Hierarchical Regression Analysis of the Effects of Destination Image Dimensions on Meaningfulness

\begin{tabular}{|l|llllllll|}
\hline \multirow{2}{*}{ Independent variables } & Model 1 & \multicolumn{3}{l}{ Model 2 } & \multicolumn{3}{c|}{ Model 3 } & \multicolumn{3}{l|}{ Model 4 } \\
\cline { 2 - 9 } & $\beta$ & $\mathrm{p}$ & $\beta$ & $\mathrm{p}$ & $\beta$ & $\mathrm{p}$ & $\beta$ & $\mathrm{p}$ \\
\hline NA & .349 & .000 & .271 & .000 & .254 & .000 & .183 & $.000^{*}$ \\
$\mathrm{CA}$ & & & .193 & .000 & .106 & .024 & .067 & .151 \\
TI & & & & & .142 & .002 & .093 & $.047^{*}$ \\
GI & & & & & & & .212 & $.000^{*}$ \\
Model summary & & & & & & & & \\
F & 97.791 & & 63.561 & & 46.006 & & 41.982 & \\
$\mathrm{R}^{2}$ & .122 & & .153 & & .164 & & .193 & \\
$\Delta \mathrm{R}^{2}$ & .121 & & .151 & & .161 & & .188 & \\
\hline
\end{tabular}

Note: $\mathrm{NA}=$ natural attractions, $\mathrm{CA}=$ cultural attractions, $\mathrm{TI}=$ tourism infrastructure, $\mathrm{GI}=$ general infrastructure * Significance at $\mathrm{p}<.05$

Source: own processing

Table 6 presents the results of hierarchical regression analysis. Results in Model 1 indicate that NA exerts a significant positive effect on meaningfulness $(\beta=.349, \mathrm{p}<.05)$. Next adding CA in Model 2 leads a significant change in $\mathrm{R}^{2}\left(\mathrm{R}^{2}=.153, \mathrm{p}<.05\right)$ and positive beta value for $\mathrm{CA}(\beta=.193)$ indicates a positive relationship with meaningfulness. In Model 3 TI was added. The explanatory power was reached at $16.4 \%\left(\mathrm{R}^{2}=.164, \mathrm{p}<.05\right)$. When GI was included, it was observed that they explained $19.3 \%$ of the variance together with NA, CA and TI $\left(\mathrm{R}^{2}=.193, \mathrm{p}<.05\right)$. The coefficient of GI was positive $(\beta=.212)$ 


\section{JOURNAL OF TOURISM AND SERVICES}

Issue 23, volume 12, ISSN 1804-5650 (Online)

www.jots.cz

which explained positive impact on meaningfulness. Since the dimension of cultural attractions was insignificant, $\mathrm{H}_{1 \mathrm{~d}}$ is partially supported.

Table 7: Results of Hierarchical Regression Analysis of the Effects of Destination Image Dimensions on Involvement

\begin{tabular}{|c|c|c|c|c|c|c|c|c|}
\hline \multirow[t]{2}{*}{ Independent variables } & \multicolumn{2}{|c|}{ Model 1} & \multicolumn{2}{|c|}{ Model 2} & \multicolumn{2}{|c|}{ Model 3} & \multicolumn{2}{|c|}{ Model 4} \\
\hline & $\beta$ & $\mathrm{p}$ & $\beta$ & $\mathrm{p}$ & $\mathrm{B}$ & $\mathrm{p}$ & $\beta$ & $\mathrm{p}$ \\
\hline$\overline{\mathrm{NA}}$ & .345 & .000 & .262 & .000 & .231 & .000 & .209 & $.000^{*}$ \\
\hline CA & & & .205 & .000 & .052 & .260 & .040 & .394 \\
\hline TI & & & & & .251 & .000 & .235 & $.000^{*}$ \\
\hline GI & & & & & & & .066 & .119 \\
\hline Model summary & & & & & & & & \\
\hline $\mathrm{F}$ & 94.961 & & 63.985 & & 54.470 & & 41.546 & \\
\hline $\mathrm{R}^{2}$ & .119 & & .154 & & .189 & & 191 & \\
\hline$\Delta \mathrm{R}^{2}$ & 117 & & .151 & & 185 & & 187 & \\
\hline
\end{tabular}

Note: $\mathrm{NA}=$ natural attractions, $\mathrm{CA}=$ cultural attractions, $\mathrm{TI}=$ tourism infrastructure, $\mathrm{GI}=$ general infrastructure * Significance at $\mathrm{p}<.05$

Source: own processing

In Model 1 (Table 7), the influence of NA was significant, and the beta value was .345, indicating that its impact on involvement was positive $(\mathrm{p}<.05)$. The explanatory power was $11.9 \%\left(\mathrm{R}^{2}=.119\right)$. Adding CA in Model 2, the explanatory power was reached at $15.4 \%\left(\mathrm{R}^{2}=.154\right)$. The $\beta$ value of CA was .205 , CA's impact on involvement was significant $(\mathrm{p}<.05)$. In Model 3, TI was added, which explained an additional of $18.9 \%$ of the variance in involvement together with NA and CA $\left(\mathrm{R}^{2}=.189, \mathrm{p}<.05\right)$. The coefficient of TI was significant and positive $(\beta=.251)$ but it was observed the effect of CA on involvement decreased $(\beta=.052)$. When GI was included in Model 4, it was observed that explanatory power was reached $19.1 \%\left(\mathrm{R}^{2}=.191, \mathrm{p}>.05\right)$. The coefficient of GI was .066 , which explained weaker effect on involvement. Since cultural attractions and general infrastructure were insignificant, $\mathrm{H}_{1 \mathrm{e}}$ is partially supported.

Table 8: Results of Hierarchical Regression Analysis of the Effects of Destination Image Dimensions on Knowledge

\begin{tabular}{|l|llllllll|}
\hline Independent variables & Model 1 & \multicolumn{3}{l}{ Model 2 } & \multicolumn{3}{l|}{ Model 3 } & Model 4 \\
\cline { 2 - 9 } & $\mathrm{B}$ & $\mathrm{p}$ & $\beta$ & $\mathrm{p}$ & $\mathrm{B}$ & $\mathrm{p}$ & $\mathrm{B}$ & $\mathrm{p}$ \\
\hline $\mathrm{NA}$ & .328 & .000 & .251 & .000 & .227 & .000 & .156 & $.000^{*}$ \\
$\mathrm{CA}$ & & & .192 & .000 & .076 & .106 & .037 & .432 \\
TI & & & & & .190 & .000 & .140 & $.003^{*}$ \\
GI & & & & & & & .215 & $.000^{*}$ \\
Model summary & & & & & & & & \\
F & 85.263 & & 56.725 & & 44.226 & & 40.736 & \\
$\mathrm{R}^{2}$ & .108 & & .139 & & .159 & & .188 & \\
$\Delta \mathrm{R}^{2}$ & .107 & & .136 & & .155 & & .184 & \\
\hline
\end{tabular}

Note: $\mathrm{NA}=$ natural attractions, $\mathrm{CA}=$ cultural attractions, $\mathrm{TI}=$ tourism infrastructure, $\mathrm{GI}=$ general infrastructure * Significance at $\mathrm{p}<.05$

Source: own processing

Regarding effects of destination image on knowledge (Table 8), results in Model 1 indicate that NA exerts a significant positive effect on knowledge $(\beta=.328)$. The explanatory power was $10.8 \%$ $\left(\mathrm{R}^{2}=.108, \mathrm{p}<.05\right)$. When CA was included in Model 2, it was observed that the effect of NA on knowledge 


\section{JOURNAL OF TOURISM AND SERVICES}

Issue 23, volume 12, ISSN 1804-5650 (Online)

www.jots.cz

decreased $(\beta=.251)$. Together, NA and CA explained $13.9 \%$ of the variance in knowledge $\left(\mathrm{R}^{2}=.139\right)$. However, CA was not significant with .432 (p>.05). In Model 3, $\beta$ Coefficient of TI is found to be positive which means TI affects knowledge positively. When TI was included, the explanatory power was reached at $15.9 \%\left(\mathrm{R}^{2}=.159\right)$. The coefficient of TI was positive $(\beta=.190)$ which explained positive impact on knowledge. In Model 4 GI was added. The coefficient of GI was significant and positive $(\beta=.215)$ but it was observed the effect of $\mathrm{CA}$ on knowledge decreased $(\beta=.037)$. The explanatory power was reached at $18.8 \%$, indicating that together NA, CA, TI and GI explained $18.8 \%$ of the variance in knowledge $\left(\mathrm{R}^{2}=.188, \mathrm{p}<.05\right)$. Since cultural attractions were not significant, $\mathrm{H}_{1 \mathrm{f}}$ is partially supported.

Results of hierarchical regression analysis, where revisit intention was dependent variables, were given in Table 9.

Table 9: Results of Hierarchical Regression Analysis of the Effects of MTE on Revisit Intention

\begin{tabular}{|c|c|c|c|c|c|c|c|c|c|c|c|c|}
\hline \multirow{2}{*}{$\begin{array}{l}\text { Independent } \\
\text { variables }\end{array}$} & \multicolumn{2}{|l|}{ Model 1} & \multicolumn{2}{|c|}{ Model 2} & \multicolumn{2}{|c|}{ Model 3} & \multicolumn{2}{|c|}{ Model 4} & \multicolumn{2}{|c|}{ Model 5} & \multicolumn{2}{|c|}{ Model 6} \\
\hline & $\beta$ & $\mathrm{p}$ & $\mathrm{B}$ & $\mathrm{p}$ & $\beta$ & $\mathrm{p}$ & $\beta$ & $\mathrm{p}$ & $\beta$ & $\mathrm{p}$ & $\beta$ & $\mathrm{p}$ \\
\hline Hedonism & .396 & $.000^{*}$ & .271 & .000 & .198 & .000 & .190 & .000 & .177 & .000 & .107 & $.019 *$ \\
\hline Novelty & & & .182 & .000 & .094 & .055 & .081 & .103 & .084 & .091 & .177 & $.001 *$ \\
\hline Local culture & & & & & .240 & .000 & .224 & .000 & .201 & .000 & -.039 & .471 \\
\hline Meaningfulness & & & & & & & .053 & .194 & .011 & .813 & .022 & .680 \\
\hline Involvement & & & & & & & & & .094 & .040 & .117 & $.028^{*}$ \\
\hline Knowledge & & & & & & & & & & & .137 & $.009 *$ \\
\hline Model summary & & & & & & & & & & & & \\
\hline $\mathrm{F}$ & 131.151 & & 74.384 & & 62.269 & & 47.169 & & 38.753 & & 32.802 & \\
\hline $\mathrm{R}^{2}$ & .157 & & .174 & & .210 & & .212 & & .217 & & .219 & \\
\hline$\Delta \mathrm{R}^{2}$ & .156 & & .172 & & .207 & & .207 & & .211 & & .213 & \\
\hline
\end{tabular}

* Significance at $\mathrm{p}<.05$

Source: own processing

In Model 1 (Table 9), the effect of hedonism on revisit intention was examined and it was observed hedonism explained $15.7 \%$ of revisit intention $\left(\mathrm{R}^{2}=.157\right)$ and the coefficient was significant and positive $(\beta=.396)$. In Model 2 , novelty was added. The explanatory power was reached at $17.4 \%\left(\mathrm{R}^{2}=.174\right.$, $\mathrm{p}<.05)$. The coefficient of novelty was positive $(\beta=.182)$ which explained positive impact on revisit intention. When local culture was included in Model 3, it was observed that the effect of novelty decreased $(\beta=.094)$. Together, hedonism, novelty and local culture explained $21 \%$ of the variance in revisit intention. In Model 4 meaningfulness was added. The coefficient of meaningfulness was .053, which explained weaker effect on revisit intention. It was not significant with .194 ( $>>.05$ ). The explanatory power was reached $21.2 \%\left(\mathrm{R}^{2}=.212\right)$. When involvement was included in Model 5, it was observed that the coefficient was .094. The explanatory power was reached at $21.7 \%$, indicating that together hedonism, novelty, local culture, meaningfulness and involvement explained $21.7 \%$ of revisit intention $\left(\mathrm{R}^{2}=.217\right.$, $\mathrm{p}<.05$ ). In Model 6, together MTE dimensions explained 21.9\% of the variance in revisit intention. When knowledge was included in Model 6, the coefficient of local culture became insignificant and negative $(\beta=-.039)$ whereas the coefficient of knowledge was significant and positive $(\beta=.137)$. According to the standardized regression coefficient, the importance of the predictive variables on revisit intention was determined as novelty, knowledge, involvement, hedonism, local culture and meaningfulness, respectively. Since local culture and meaningfulness were not significant, $\mathrm{H}_{2}$ is partially supported.

\section{Discussion and Conclusion}




\section{JOURNAL OF TOURISM AND SERVICES}

Issue 23, volume 12, ISSN 1804-5650 (Online)

www.jots.cz

Due to technological innovations and the existence of a more informed, demanding consumer, tourism businesses have started to offer personalized experiences rather than concentrating on facilities and services. In terms of tourism businesses, one of the most important keys to gaining competitive advantage and maintaining their existence is to provide consumers with unique, extraordinary and memorable experiences. It is broadly acknowledged that the destination image affects the decision making, destination selection, post-travel reviews and future behaviour (Zhang et al., 2018: 326). Therefore, this study examined the influence of destination image dimensions on MTE, and the influence of MTE on revisit intention.

The research was conducted in Antalya, one of the most visited cities in Turkey. Explanatory factor analysis, confirmatory factor analysis and hierarchical regression analysis were used in the analysis, which was evaluated over 707 questionnaires. According to the confirmatory factor analysis for the destination image scale, the 4-dimensional factor structure of the destination image was confirmed. Among 7 factors of the memorable tourism experience scale, the refreshment factor was excluded since it was not suitable for the structure. Therefore, analyses were evaluated on six factors. It is suggested that the reliability coefficient will be sufficient since revisit intention scale is not suitable for factor analysis as a one-dimensional structure.

According to the results of the research, it was determined that the destination image contributed to the formation of MTE. The dimensions of the destination image, namely natural attractions, cultural attractions, tourism infrastructure and general infrastructure, positively affect hedonism and local culture. But dimensions of destination image partly affect novelty, involvement, meaningfulness, and knowledge According to Kim, the activities and tourism infrastructure in the destination satisfy the tourists' desire for hedonism and innovation ( $\mathrm{Kim}, 2014: 41$ ). As stated by Matos, there is a positive relationship between the destination image and the hedonism dimension (Matos, 2014: 223). Mahdzar et al. (2015: 36) found in their studies that destination characteristics have a positive effect on the dimensions of novelty, local culture, involvement and meaningfulness of MTE. According to the perceptions of Russian tourists in Antalya, Ersoy (2015) found a positive relationship between the destination image and MTE. In line with previous research, the findings of the current study confirmed the positive effect of destination image on hedonism and local culture. The friendliness of the local people can be considered as a trigger for tourists to experience MTE. In a study conducted with students, Morgan and Xu (2009) found that the most important contribution to the formation of MTE was destination attraction with $13.1 \%$ and cultural attraction with $11.9 \%$ in the second place. The results indicated that 'natural attractions' and 'general infrastructure' were the two most prevalent images held by respondents that affects positively MTE. Destination image affects the local culture dimensions most. In other words, $22.9 \%$ of the local culture depends on destination image.

Regarding the second objective, whether there was an influence of MTE on revisit intention, the results revealed that there was a positive influence of MTE on revisit intention consistent with previous findings (Ali et al., 2014: 277; Demir, 2018: 124; Duman \& Mattila, 2005: 319; Kim, 2018: 863; Kim \& Ritchie, 2014: 328; Mahdzar et al.., 2015: 37; Sthapit, 2013: 74; Zhang et al.., 2018: 333; Zhong et al.., 2017: 210). In terms of dimensions of MTE, hedonism, novelty, involvement and knowledge positively influence revisit intention. However, in some studies, it has been observed that consumers tend to perceive the service sector higher than the experience sector (Chang, 2018: 55). In their study, Moon and Han (2018: 78) examined the influence of perception of destination attributes to the experience quality of Chinese tourists and found that local culture and infrastructure negatively affect travel satisfaction. Similarly, our findings indicate that local culture and meaningfulness' influence on revisit intention have not been supported. Specifically, local culture had a negative impact on revisit intention. This inconsistency might be explained by accommodation enterprises which apply 'all-inclusive system' that offers a variety of decent services at affordable costs for individuals. As a result of being dependent on the hotel service throughout the holiday, tourists may not want to go outside the hotel and may not have social interaction with the local people. 


\section{JOURNAL OF TOURISM AND SERVICES}

Issue 23, volume 12, ISSN 1804-5650 (Online)

www.jots.cz

The findings and discussions resulting from the study can provide tourism officials and destination managers' evidence of the important role of destination image on the formation of MTE, which will affect tourists' revisit intention. Since the destination image is an important antecedent of MTE, cultural attractions, tourism infrastructure, and general infrastructure should be continuously improved. As, a novelty which is one of the dimensions of MTE, is an important antecedent of revisit intention, innovations and initiatives related to the sector should be constantly monitored, and tourists should be informed through information communication technologies. Since novelty-seeking travelers do not intend to revisit the same destination despite the fact that they have a memorable experience (Chandralal \& Valenzuela, 2013), businesses could implement product enhancements and modifications to attract visitors seeking novelty in the travel context. Considering the effect of involvement and knowledge on revisit intention, accommodation establishments can provide opportunities for tourists to increase their knowledge and skills such as cooking classes, massage techniques, swimming and diving lessons. In terms of destination, increasing the activities such as festivals, competitions, exhibitions and encouraging tourists to participate in these activities could contribute to the formation of MTE. Similarly, offering tourists more opportunities to learn about local history, cultures, and lifestyles can add value to their experience.

Despite the fact that the current study results have highlighted several important issues, some limitations need to be considered in future research. The survey conducted to tour groups concentrated in certain regions during the summer season is the limitation of the study. Since the convenience sampling technique was used in the current study, results cannot be generalized to the target population. As the limited number of destination attributes was examined in this study, future research should be extended to include the other attributes of destination that are not included in this study. Similarly, further studies should also examine MTE by adding different dimensions. In this study, the effects of destination image on MTE were examined. On the contrary, the effects of MTE on destination image may also be a subject of future research. Moreover, this study was only conducted in Antalya, which is the most popular destination in Turkey. Further studies should conduct similar studies in different destinations during different seasons to understand if the different periods of the year change tourists' perceptions of image and MTE. In addition, in future studies, country comparisons can be made with a study involving the participation of different countries. Meanwhile, it can be investigated whether the memorable tourism experience differs for different nations.

\section{References}

1. Accommodation statistics annual bulletin summary. (2019). Ministry of Culture and Tourism. Access address: https://yigm.ktb.gov.tr/Eklenti/71555,konaklama-istatistikleri-2019-yillikbulten-ozetipdf.pdf?0

2. Ali, F., Hussain, K. and Ragavan N. A. (2014). Memorable customer experience: examining the effects of customers experience on memories and loyalty in Malaysian resort hotels. Procedia Social and Behavioral Sciences, 144(August), 273-279

3. Alhemoud, M. A. and Armstrong, E. G. (1996). Image of tourism attractions in Kuwait. Journal of Travel Research, 34 (Spring): 76-80

4. Aslan, Hakan (2018). Turistlerin destinasyonda yaşadıkları yaratıcı deneyimlerin destinasyon hatırlanabilirliği ve sadakat üzerine etkisi. Yayınlanmamış Yüksek Lisans Tezi, Muğla Sitkı Koçman Üniversitesi - Sosyal Bilimler Enstitüsü

5. Baloglu, S. and McClearly, K. W. (1999). A model of destination image formation. Annals of Tourism Research, 26(4), 868-897

6. Barnes, S. J., Mattson, J. and Sorensen, F. (2016). Remembered experiences and revisit intentions: a longitudinal study of safari park visitors. Tourism Management, 57, 286-294 


\section{JOURNAL OF TOURISM AND SERVICES}

Issue 23, volume 12, ISSN 1804-5650 (Online)

www.jots.cz

7. Beerli, A. and Martin, J. D. (2004). Tourists' characteristics and the perceived image of tourist destinations: a quantitative analysis — a case study of Lanzarote, Spain. Tourism Management, 25, 623-636

8. Bigne, E. J., Sanchez, M. I. and Sanchez, J. (2001). Tourism image, evaluation variables and after purchase behaviour: inter-relationship. Tourism Management, 22(2001), 607-616

9. Buhalis, D. (2000). Marketing the competitive destination of the future. Tourism Management, 21 (1): $97-116$

10. Chandralal, L. and Valenzuela, F. (2013). Exploring memorable tourism experiences: antecedents and behavioural outcomes. Journal of Economics, Business and Management, 1(2), 177-181

11. Chang, Seohee (2018). Experience economy in hospitality and tourism: Gain and loss values for service and experience. Tourism Management, 64, 55-63

12. Chen, C. and Tsai, D. (2007). How destination image and evaluative factors affect behavioral intentions? Tourism Management, 28, 1115-1122

13. Chen, H. and Rahman, I. (2018). Cultural tourism: an analysis of engagement, cultural contact, memorable tourism experience and destination loyalty. Tourism Management Perspectives, 26(2018), 153-163

14. Cooper, C. and Hall, M. C. (2008). Contemporary Tourism: An International Approach. ButterworthHeinemann

15. Crompton, J. L. (1979). An assessment of the image of Mexico as a vacation destination and the influence of geographical location upon that image. Journal of Travel Research, 17(4), 18-23

16. De Matos, N. M. (2014). The impacts of tourism experiences in the destination image: a marketing perspective. Doctoral dissertation. Universidade Do Algarve Faculdade De Economia

17. De Vita, G., Tekaya, A. And Wang, C. L. (2010). Asset specificity's impact on outsourcing relationship performance: A disaggregated analysis by buyer-supplier asset specificity dimensions. Journal of Business Research, 63, 657-666

18. Demir, Seda (2018). Kuşaklar açısından unutulmaz turizm deneyimleri algısının satın alma sonrası davranışlar üzerindeki etkisi. Yayınlanmamış Yüksek Lisans Tezi, Trakya Üniversitesi - Sosyal Bilimler Enstitüsü

19. Duman, T. and Mattila, A. S. (2005). The role of affective factors on perceived cruise vacation value. Tourism Management, 26 (2005), 311-323

20. Echtner, C. M. and Ritchie, J. R. B. (2003). The meaning and measurement of destination image. The Journal of Tourism Studies, 14(1), 37-48

21. Ersoy, Mücahit (2015). Türkiye'yi ziyaret eden Rus turistlerin destinasyon imaj algilamaları ve hatırlanabilir turizm deneyimleri üzerine bir araştırma. Yayınlanmamış Yüksek Lisans Tezi, Adana Alparslan Türkeş Bilim ve Teknoloji Üniversitesi - Sosyal Bilimler Enstitüsü

22. Fabrigar L. R., MacCallum R. C., Wegener D. T., Strahan E. J. (1999). Evaluating the use of exploratory factor analysis in psychological research. Psychological Methods, 4(3):272-299. doi: 10.1037/1082-989X.4.3.272.

23. Fakeye, P. C. and Crompton, J. L. (1991). Image differences between prospective, first-time, and repeat visitors to the lower Rio Grande Valley. Journal of Travel Research, 30(2), 10-16

24. Gallarza, M. G., Saura, I. G., and Garcia, H. K. vd. (2002). Destination image: towards a conceptual framework. Annals of Tourism Research, 22(1), 56-78

25. Gegez, E. A. (2014). Pazarlama arastırmalar. İstanbul: Beta Publishing

26. Global Destination Cities Index 2019. Access address: https://newsroom.mastercard.com/wpcontent/uploads/2019/09/GDCI-Global-Report-FINAL-1.pdf

27. Gunn, C.A. (1997). Vacationscape: developing tourist areas, Third Edition, Taylor \& Francis, Washington D.C.

28. Hoch, S. J. and Deighton, J. (1989). Managing what consumers learn from experience. Journal of Marketing, 53 (April 1989), 1-2 


\section{JOURNAL OF TOURISM AND SERVICES}

Issue 23, volume 12, ISSN 1804-5650 (Online)

www.jots.cz

29. Holbrook, M. B. and Hirschman, E. C. (1982). The experiential aspects of consumption: consumer fantasies, feelings, and fun. Journal of Consumer Research, 9 (1982), 132-140

30. Hui, T. K., and Wan, T. W. D. (2003). Singapore's 1mage as a tourist destination. International Journal of Tourism Research, 5, 305-313

31. Ipsos Report (2020). Global Trends, tourism and Turkey. Access address: https://www.ipsos.com/tr-tr/global-trendler-turizm-ve-turkiye

32. Kim, J. (2010). Determining the factors affecting the memorable nature of travel experiences. Journal of Travel \& Tourism Marketing, 27(8), 780-796

33. Kim, J., Ritchie, J. R. B., and McCormick, B. (2012). Development of a scale to measure memorable tourism experiences. Journal of Travel Research, 51 (1), 12-25

34. Kim, J. (2014). the antecedents of memorable tourism experiences: the development of a scale to measure the destination attributes associated with memorable experiences. Tourism Management, 44, 34-45

35. Kim, J., and Ritchie, J. R. B. (2014). Cross-cultural validation of a memorable tourism experience scale (MTES). Journal of Travel Research, 53(3), 323-335

36. Kim, Bommae (2016). Hierarchical linear regression. Access address: https://data.library.virginia.edu/hierarchical-linear-regression

37. Kim, J. (2018). The impact of memorable tourism experiences on loyalty behaviors: the mediating effects of destination image and satisfaction. Journal of Travel Research, 57(7), 856-870

38. Kotler, P., Haider, D. H., and Rein, I. (1993). Marketing places: attracting investment, industry and tourism to cities, states and nations. The Free Press a Division of Macmillan, Inc., New York

39. Lyu, C., Yang, J., Zhang, F., Teo, T. S. H., Mu, T. (2020). How do knowledge characteristics affect firm's knowledge sharing intention in interfirm cooperation? An empirical study. Journal of Business Research, 115, 48-60

40. MacInnis, D. J. and Price, L. L. (1987). The role of imagery in information processing: review and extension. Journal of Consumer Research, 13(4), 473-491

41. Mahdzar, M., Shuib, A., Ramachandran, S., and Afandi, S. H. M. (2015). The role of destination attributes and memorable tourism experience in understanding tourist revisit intentions. AmericanEurasian J. Agric. \& Environ. Sci., 15(Tourism \& Environment, Social and Management Sciences), 32-39

42. Martínez, S. C. and Alvarez, M. D. (2010). Country versus destination image in a developing country. Journal of Travel \& Tourism Marketing, 27(7), 748-764

43. Ministry of Culture and Tourism. Access address:http://yigm.kulturturizm.gov.tr/TR9851/turizm-istatistikleri.html, 08.01.2019

44. Ministry of Culture and Tourism. Access address: https://yigm.ktb.gov.tr/TR-201136/turizmyatirim-ve-isletme-bakanlik-belgeli-tesis-istati-.html

45. Moon, H. and Han, H. (2018). Destination attributes influencing Chinese travelers' perceptions of experience quality and intentions for island tourism: A case of Jeju Island. Tourism Management Perspectives, 28, 71-82

46. Morgan, M. and Xu, F. (2009). Student travel experiences: memories and dreams. Journal of Hospitality Marketing \& Management, 18, 216-236

47. Nadeau, J., Heslop, L., O'Reilly, N., and Luk, P. (2008). Destination in a country image context. Annals of Tourism Research, 35(1), 84-106

48. Nunnally, J. C. (1978). Psychometric theory (2nd ed). New York: McGraw-Hill.

49. Oh, H., Fiore, A. M., and Jeoung, M. (2007). Measuring experience economy concepts: tourism applications. Journal of Travel Research, 46, 119-132

50. Pine, B. J. and Gilmore, J. (1998). Wellcome to the experience economy. Harvard Business Review, July-August 1998, HBS Press 


\section{JOURNAL OF TOURISM AND SERVICES}

Issue 23, volume 12, ISSN 1804-5650 (Online)

www.jots.cz

51. Souiden, N., Ladhari, R., and Chiadmi, N. E. (2017). Destination personality and destination image. Journal of Hospitality and Tourism Management, 32, 54-70

52. Sthapit, E. (2013). Tourists' perceptions of memorable experiences: testing the memorable tourism experience scale (MTEs) among tourists to Rovaniemi, Lapland. Unpublished Master's Thesis, University of Lapland- Faculty of Social Sciences

53. Tarssanen, S. (2009). Handbook for experience stagers. 5th Edition. Rovaniemi: Lapland Center of Expertise for the Experience Industry

54. Tasci, A. D. A. and Gartner, W. C. (2007). Destination image and its functional relationships. Journal of Travel Research, 45(4), 413-425

55. Tukamushaba, E. K., Xiao, H., and Ladkin, A. (2016). The effect of tourists' perceptions of a tourism product on memorable travel experience: implications for destination branding. De Gruyter Open, EJTHR, 7(1):2-12

56. Tung, V. W.S. and Ritchie, J.R. B. (2011). Exploring the essence of memorable tourism experiences. Annals of Tourism Research, 38 (4), 1367-1386

57. Türkay, Oğuz and Saraç, Ömer (2019). Altyap1, üstyapı ve çevre sorunlarının turist şikâyetleri kapsamında değerlendirilmesi ve yerel yönetimlerin çözüm potansiyeli: Antalya örneği. Gümüşhane Üniversitesi Sosyal Bilimler Enstitüsü Elektronik Dergisi, 10(Ek Say1), 98-110

58. Unal, A. and Bayar, S. B. (2020). Destinasyonlara ilişkin hatırlanabilir deneyimlerin turistlerin tekrar seyahat niyetlerine etkileri: Side örneği. Uluslararası Türk Dünyası Turizm Arastırmalar Dergisi, $5(1), 1-13$

59. Üner, M.M., Sökmen, A. and Birkan, İ. (2006). Türkiye'de her şey dahil uygulamasının konaklama işletmeleri üzerindeki etkisi: Antalya örneği. Anatolia: Turizm Araştırmalar Dergisi, 17(1), 35-50

60. Zhang, H., Wu, Y., and Buhalis, D. (2018). A model of perceived image, memorable tourism experiences and revisit intention. Journal of Destination Marketing \& Management, 8, 326-336

61. Zhong, Y. Y., Busser, J., and Baloglu, S. (2017). A model of memorable tourism experience: the effects on satisfaction, affective commitment, and storytelling. Tourism Analysis, 22, 201-217

\section{Brief description of Authors:}

\section{Didem Kutlu, PhD.}

\section{PhD. Lecturer}

ORCID ID: https://orcid.org/0000-0003-3354-5202

Program of Tourism and Travel Services, Vocational School of Social Sciences, Akdeniz University, Turkey, Bayındır Mahallesi, Palmiye Caddesi, Çallı Mevki, No:43 07030 Muratpaşa /ANTALYA Email: didemkutlu76@yahoo.com

Didem Kutlu is a lecturer at Vocational School of Social Sciences, Akdeniz University. Her main field is marketing and tourism marketing. Her research interest (according to publications) is destination image, tourism experience, electronic word of mouth, and travel agency studies.

\section{Prof. Hasan Ayyildiz}

ORCID ID: https://orcid.org/0000-0003-1954-6719

Production Management and Marketing, Faculty of Economics and Administrative Sciences, Karadeniz Technical University, 61080 Ortahisar / Trabzon / TÜRKIYE

Email:ayyildiz@ktu.edu.tr

His main field of research is product management and marketing. In addition, his research interest is a strategic marketing and brand management, entrepreneurship and innovation management, country image, destination image, and selected consumer behavior studies. In addition, he is head of Continuing Education Application and Research Center. 